\title{
Teaching NeuroImages: Spinal Neurosarcoidosis
}

\section{An Eccentric Manifestation}

David French, MD, Fábio A. Nascimento, MD, Ya Xu, MD, and S. Richard Dunham, MD

Neurology ${ }^{\circledR}$ 2021;96:e643-e644. doi:10.1212/WNL.0000000000010802

Figure 1 MRI C-Spine

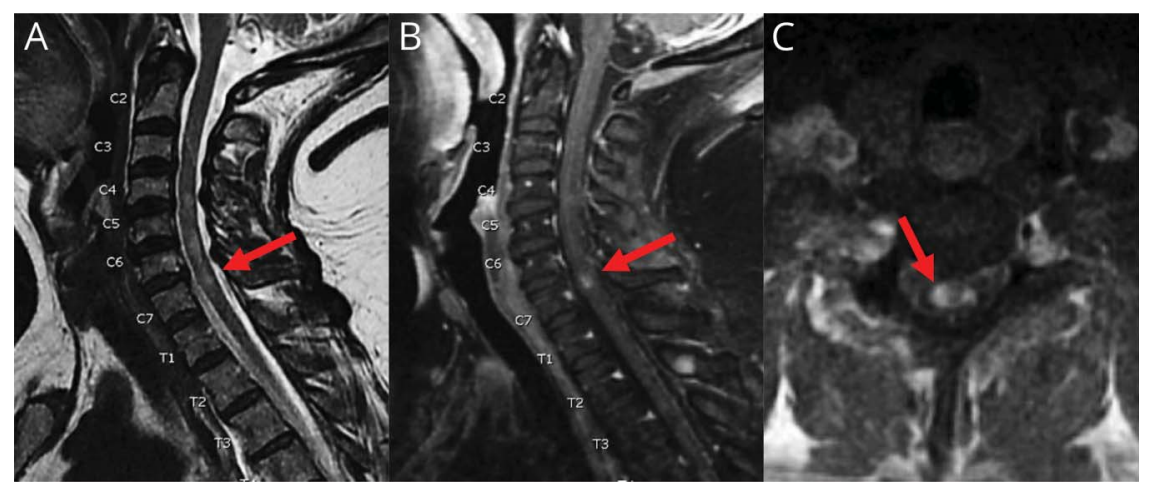

(A) Sagittal T2 with patchy signal at C4-7. (B) T1 with contrast with C7 cord enhancement. (C) Axial T2 with subpial enhancement.

A 56-year-old woman with a history of remote T11 traumatic spinal transection and residual paraplegia presented with subacute left arm pain, weakness, and sensory loss. MRI spine showed C4-7 patchy T2 cord signal and an eccentric enhancing focus with subpial involvement (figure 1). CSF studies were unremarkable, including negative oligoclonal bands. An extensive immunologic and infectious evaluation for subacute myelitis was unrevealing. However, given the subpial and intramedullary involvement in the spine, ${ }^{1,2}$ a systemic search for sarcoidosis was initiated. Asymptomatic hilar lymphadenopathy was diagnosed with CT chest, and a subsequent lymph node biopsy confirmed the clinical suspicion (figure 2). She was diagnosed with probable neurosarcoidosis ${ }^{1,2}$ and started on immunosuppresion.

\section{Study Funding}

No targeted funding reported.

\section{Disclosure}

D. French reports no disclosures relevant to the manuscript. F.A. Nascimento is a member of the Neurology Resident \& Fellow Section Editorial Team. Y. Xu reports no disclosures relevant to the manuscript. S.R. Dunham reports no disclosures relevant to the manuscript. Go to Neurology.org/ $\mathrm{N}$ for full disclosures.

\author{
Correspondence \\ Dr. French \\ David.French@bcm.edu
}

\section{MORE ONLINE}

\section{$\rightarrow$ Teaching slides \\ links.lww.com/WNL/ \\ B211}

From the Department of Neurology (D.V., F.A.N.), Baylor College of Medicine Houston, TX; and Departments of Pathology and Immunology (Y.X.), and Neurology (S.R.D.), Baylor College of Medicine, Houston TX.

Go to Neurology.org/N for full disclosures. 


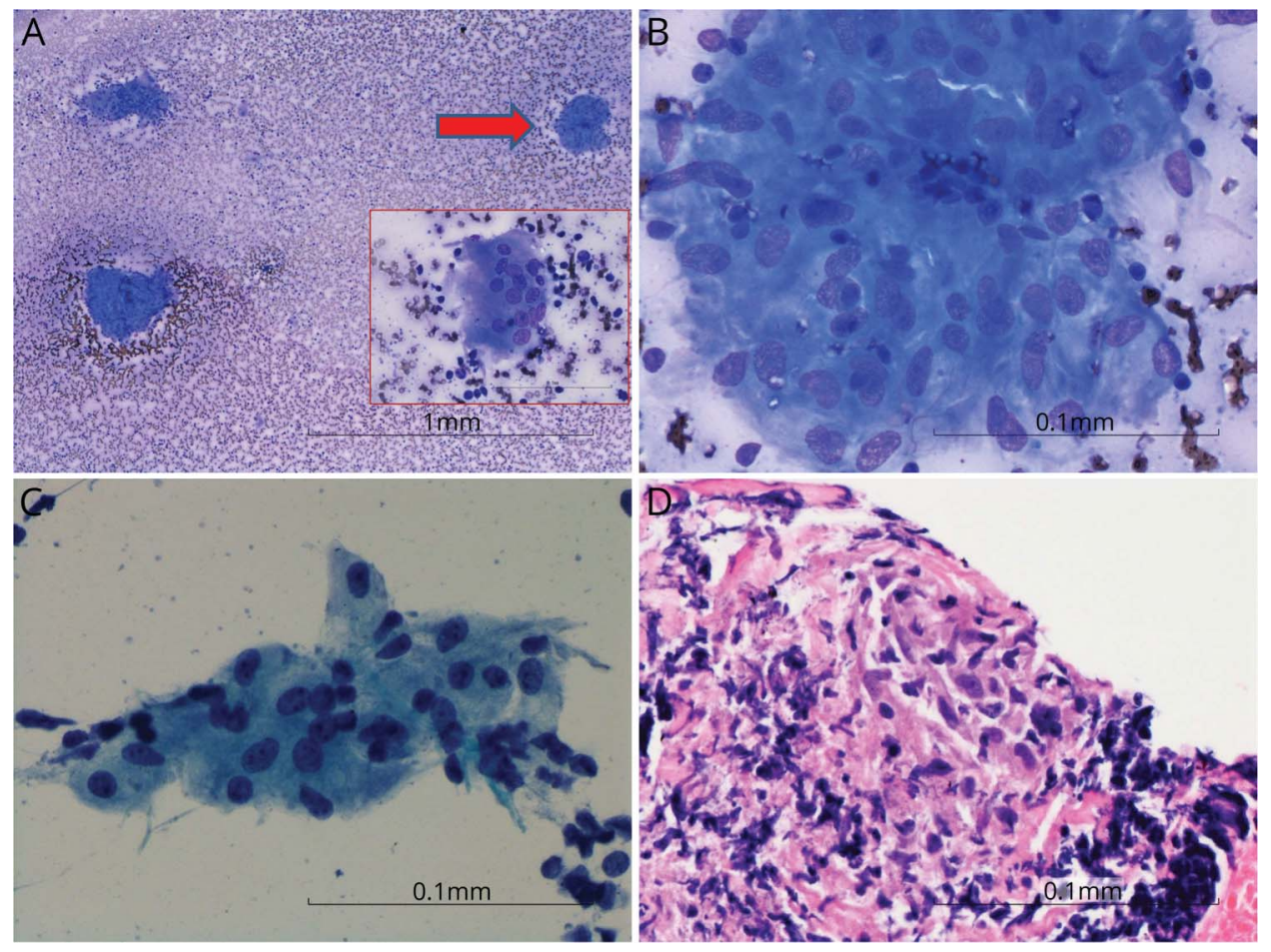

(A) Diff-Quik smear with 3 granulomas (×40). (B) Granuloma (×400) (C) Epithelioid histiocytes from granuloma. (D) H\&E cell block with noncaseating granuloma.

Appendix Authors

\begin{tabular}{lll}
\hline Name & Location & Contribution \\
\hline $\begin{array}{l}\text { David } \\
\text { French, MD }\end{array}$ & $\begin{array}{l}\text { Baylor College of } \\
\text { Medicine, } \\
\text { Houston }\end{array}$ & $\begin{array}{l}\text { Drafted the manuscript for } \\
\text { intellectual content, and collected } \\
\text { and analyzed the data }\end{array}$ \\
\hline $\begin{array}{l}\text { Fábio A. } \\
\text { Nascimento, } \\
\text { MD }\end{array}$ & $\begin{array}{l}\text { Baylor College of } \\
\text { Medicine, } \\
\text { Houston }\end{array}$ & $\begin{array}{l}\text { Revised the manuscript for } \\
\text { intellectual content, and collected } \\
\text { and analyzed the data }\end{array}$ \\
\hline Ya Xu, MD & $\begin{array}{l}\text { Baylor College of } \\
\text { Medicine, } \\
\text { Houston }\end{array}$ & $\begin{array}{l}\text { Processed and organized the } \\
\text { pathology images }\end{array}$ \\
\hline $\begin{array}{l}\text { S. Richard } \\
\text { Dunham, MD }\end{array}$ & $\begin{array}{l}\text { Baylor College of } \\
\text { Medicine, } \\
\text { Houston }\end{array}$ & $\begin{array}{l}\text { Interpreted the data, supervised the } \\
\text { study, and provided the final } \\
\text { approval }\end{array}$ \\
\hline
\end{tabular}

\section{References}

1. Stern BJ, Royal W, Gelfand JM, et al. Definition and consensus diagnostic criteria for neurosarcoidosis: from the neurosarcoidosis consortium consensus group. JAMA Neurol 2018;75:1546-1553.

2. Zalewski NL, Krecke KN, Weinshenker BG, et al. Central canal enhancement and the trident sign in spinal cord sarcoidosis. Neurology 2016;87:743-744. 


\section{Neurology}

Teaching NeuroImages: Spinal Neurosarcoidosis: An Eccentric Manifestation

David French, Fábio A. Nascimento, Ya Xu, et al.

Neurology 2021;96; e643-e644 Published Online before print September 9, 2020

DOI 10.1212/WNL.0000000000010802

This information is current as of September 9, 2020

\section{Updated Information \&} Services

References

Subspecialty Collections

Permissions \& Licensing

Reprints including high resolution figures, can be found at: http://n.neurology.org/content/96/4/e643.full

This article cites 2 articles, 1 of which you can access for free at: http://n.neurology.org/content/96/4/e643.full\#ref-list-1

This article, along with others on similar topics, appears in the following collection(s):

All Spinal Cord

http://n.neurology.org/cgi/collection/all_spinal_cord MRI

http://n.neurology.org/cgi/collection/mri

Information about reproducing this article in parts (figures,tables) or in its entirety can be found online at:

http://www.neurology.org/about/about_the_journal\#permissions

Information about ordering reprints can be found online:

http://n.neurology.org/subscribers/advertise

Neurology ${ }^{\circledR}$ is the official journal of the American Academy of Neurology. Published continuously since 1951 , it is now a weekly with 48 issues per year. Copyright (C) 2020 American Academy of Neurology. All rights reserved. Print ISSN: 0028-3878. Online ISSN: 1526-632X.

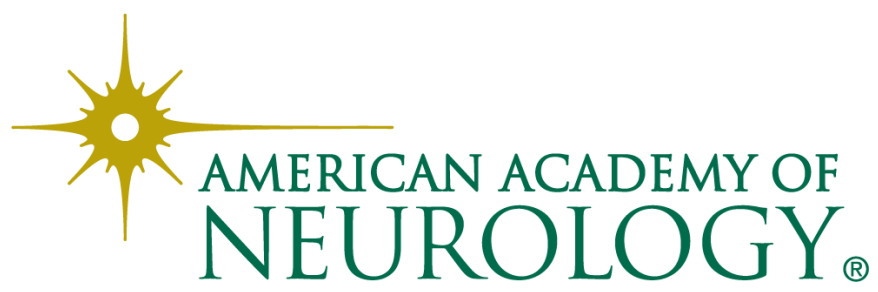

